Utah State University

DigitalCommons@USU

The Bark Beetles, Fuels, and Fire Bibliography

Quinney Natural Resources Research Library,

S.J. and Jessie E.

1958

\title{
The Effects of Woodpeckers on Populations of the Engelmann Spruce Beetle
}

F B. Knight

Follow this and additional works at: https://digitalcommons.usu.edu/barkbeetles

Part of the Ecology and Evolutionary Biology Commons, Entomology Commons, Forest Biology Commons, Forest Management Commons, and the Wood Science and Pulp, Paper Technology Commons

\section{Recommended Citation}

Knight, F. (1958). Effects of woodpeckers on populations of the Engelmann spruce beetle. Journal of Economic Entomology, 51(5): 603-607.

This Article is brought to you for free and open access by the Quinney Natural Resources Research Library, S.J. and Jessie E. at DigitalCommons@USU. It has been accepted for inclusion in The Bark Beetles, Fuels, and Fire Bibliography by an authorized administrator of DigitalCommons@USU. For more information, please contact digitalcommons@usu.edu.

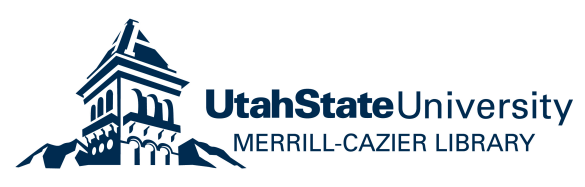




\section{Utah State University}

\section{DigitalCommons@USU}

The Bark Beetles, Fuels, and Fire Bibliography

Quinney Natural Resources Research Library, S.J. and Jessie E.

1958

\section{The Effects of Woodpeckers on Populations of the Engelmann Spruce Beetle}

F B. Knight

Follow this and additional works at: https://digitalcommons.usu.edu/barkbeetles

Part of the Ecology and Evolutionary Biology Commons, Entomology Commons, Forest Biology Commons, Forest Management Commons, and the Wood Science and Pulp, Paper Technology Commons

\section{Recommended Citation}

Knight, F. (1958). Effects of woodpeckers on populations of the Engelmann spruce beetle. Journal of Economic Entomology, 51(5): 603-607.

This Article is brought to you for free and open access by the Quinney Natural Resources Research Library, S.J. and Jessie E. at DigitalCommons@USU. It has been accepted for inclusion in The Bark Beetles, Fuels, and Fire Bibliography by an authorized administrator of DigitalCommons@USU. For more information, please contact dylan.burns@usu.edu.

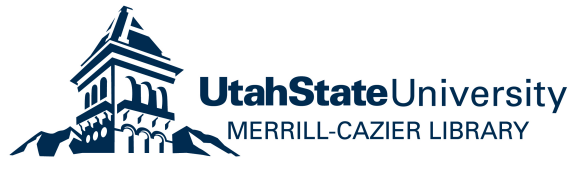


and the plants lived longer than under uncontrolled conditions. There were no real differences in either category. for population levels from 7 to 15 aphids per plant.

Table 1 also shows that one aphid per plant allowed to teed and multiply had approximately the same effect as six aphids per plant feeding under controlled conditions, and four aphids per plant the same as seven to nine under the same respective conditions. 'The number of aphids killing the plants under uncontrolled conditions was not determined. When the plants were wilting, many aphids left because of overcrowding and lack of food. Theoretically, one aphid produced on an average three young per day, which matured in about $\gamma$ to 10 days. After 12.6 days, the average life of 10 plants infested with one aphid each, approximately 313 aphids were produced. Obviously, a young plant could not support such a high population of aphids. The number of aphids at the saturation point was undoubtedly much smaller than the theoretical figure.

DAMAGE SYMPTOMS.-Plants infested with one to three aphids under controlled population conditions showed acute toxemia symptoms. Yellow vein clearing and chlorotic mottling were very noticeable on the first true leaflet after 5 to 7 days. No symptoms were noted on the cotyledons. As the plants continued slow growth, vein clearing and mottling became more pronounced and extensive, and eventually most of them wilted and died.

Plants infested with three to five aphids exhibited very severe stunting associated with typical vein clearing and mottling, and finally died. On dying plants the cotyledons dried up first, followed by the first true leaflet. Later the first and second trifoliolate leaves dried up, leaving a dried, shriveled stem. Many plants, especially those infested with 7 to 15 aphids under both test conditions, died so quickly that no symptoms of vein clearing or mottling were observed. All the check plants survived and were growing vigorously by the end of the tests.

Conclustons.-These studies confirm earlier reports that one aphid per plant, and resulting offspring, injured and killed seedling alfalfa in a very short time. This was true provided the insect fed and produced progeny under normal circumstances. Since seedlings are extremely susceptible, young stands should be examined for aphids as soon as the plants have germinated and examinations repeated at 5 -day intervals until the alfalfa becomes well established.

\section{Refarences Crteid}

Dickson, R. C., and H. T. Reynolds. 1955. The yellow clover aphid on alfalfa. California Agric. $9(7): 4,15$.

Dickson, R. C., Edward F. Laird, Jr., and George R. Pesho. 1955. The spotted alfalfa aphid (yellow clover aphid) on alfalfa. Hilgardia 24(5): 93-118.

Dobson, R. C., and J. G. Watts. 195\%. Spotted alfalfa aphid occurrence on seedling alfalfa as influenced by systemic insecticides and varieties. Jour. Econ.. Ent. $50(2): 132-5$.

Reynolds, Harold T., Ray F. Smith, and John E. Swift. 1956 Insecticides for alfalfa aphid. California Agric. 10(5): $11-12,16$.

Tuttle, Donald M. 1956. The spotted alfalfa aphid (a progress report). Univ. Arizona Agric. Expt. Sta. Rept. 131, 3 pp.

\title{
The Effects of Woodpeckers on Populations of the Engelmann Spruce Beetle ${ }^{1}$
}

\author{
F. B. KNIGHT2
}

Abstract factor in the natural reduction of Engelmann spruce beetle populations. A means of assessing their value has been developed.

Five classifications of woodpecker feeding based on woodpecker work on 225 trees were studied.

An analysis of population measurements showed a correlation between beetle survival and the woodpecker classification and the intensity of infestation in each tree. A heavy woodpecker classification resulted in very little survival at all intensities of infestation. Survival increased both with an increase in intensity
Woodpeckers have been recognized for many years as a major

of infestation and a lower woodpecker classification.

The average reduction in populations increased progressively from 45 to 98 per cent as the woodpecker classification, which was highly correlated with caged survival, progressed from light to heavy. After woodpecker feeding, numerical survival of beetles was greatest in the moderate classification.

The effects of woodpeckers on populations of the Engelmann spruce beetle can be evaluated by classifying woodpecker work and measuring the intensity of beetle infestation in the tree.

Three species of woodpeckers are important natural control agents of the Engelmann spruce beetle, Dendroctonus engelmanni Hopk. These are the northern threetoed, Picoides tridactylus dorsalis Baird; the downy, Dendrocopos pubescens leucurus (Hartlaub); and the hairy, Dendrocopos villosus monticolae (Anthony).

The Engelmann spruce beetle is a native insect of spruce forests of the central Rocky Mountains. During epidemic outbreaks, it may kill vast stands of spruce in a few years. Outbreaks appear to result from the increase of beetles in trees that have been blown over by strong winds. Such was the case in Colorado between 1939 and 1952, when more than 5 billion board feet of spruce were killed (U. S. Forest Service 1955).

The catastrophic losses were finally stopped by a com-

1 Accepted for publication February 24,1958

2 Entomologist, Rocky Mountain Forest and Range Experiment Station, Forest Service, U. S. Dept. of Agriculture. The station maintains central headquarters at Fort Collins, Colorado, in cooperation with Colorado State University. 


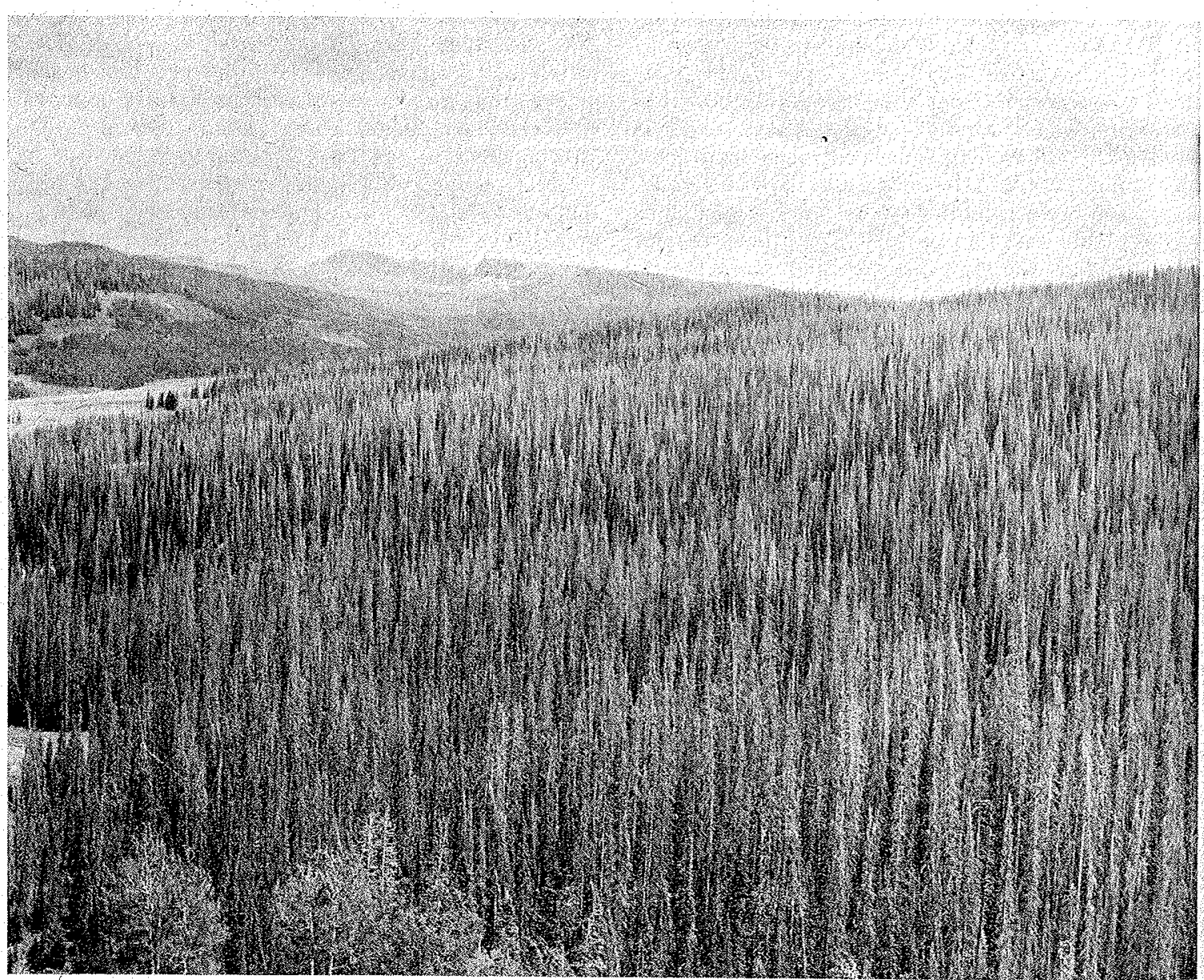

FIG, 1.-All of these Engelmann spruce trees have been killed by the Engelmann spruce beetle.

bination of chemical control and natural mortality factors. Among the natural factors, woodpeckers were of primary importance. Beetle populations in many of the infested stands bordering the major outbreak areas were reduced to endemic numbers by woodpeckers.

This paper was planned as a report on one mortality factor, the woodpeckers. During most years, they cause great reductions in beetle populations. However, other factors also produce mortality and during some years may be more important than woodpeckers. For example, during the winter of 1950-51, abnormally cold tempertures killed most of the brood above snowline in the spruce beetle epidemic in Colorado.

In addition, many parasites and predators, other than the woodpecker, are important. These attack all stages of the insect. Some examples of these are:

1. Internal nematodes, which reduce egg production.

2. Mites-predators.

3. Coeloides dendroctoni Cush.- -an important parasite of the larval stage.

4. Medetera aldrichii Wheeler-a predator.

5. Thanasimus nigriventris Lec.-a predator.

Endemic populations of the spruce beetle are maintained in over-mature standing trees and scattered, windthrown trees. Following severe windstorms and blow down, the populations increase to an epidemic status Beetles multiply while protected from woodpeckers and other natural enemies. The large populations that emerge from the wind-felled trees attack standing green trees. Beetles continue to increase in numbers because wood. peckers and other natural control agents are not able to hold them in check. The epidemic may continue until it is stopped by a combination of direct control and natural mortality factors or by a lack of trees to infest (fig. 1).

Woodpeckers eat many of the spruce beetles and kill others indirectly by removing large quantities of bark (fig. 2), with the resultant drying of the remaining bark. and insects (Massey \& Wygant 1954). Hutchison (1951) found that during spruce beetle epidemics about $99 \%$ of the winter food of woodpeckers consisted of spruce beetle larvae and adults. Massey \& Wygant (1954) observed during the summer that $65 \%$ of the food was Engelmann spruce beetle.

Hutchison (1951) reported that woodpeckers caused a mortality of $\mathbf{5 5 \%}$ of the spruce beetles in the study area in which he was working. This study was mäde during an epidemic covering thousands of acres. Under the circunstances, one would expect a minimum effectiveness of the woodpecker because of the tremendous supply of food. In smaller areas of infestation or in declining epidemics, one 


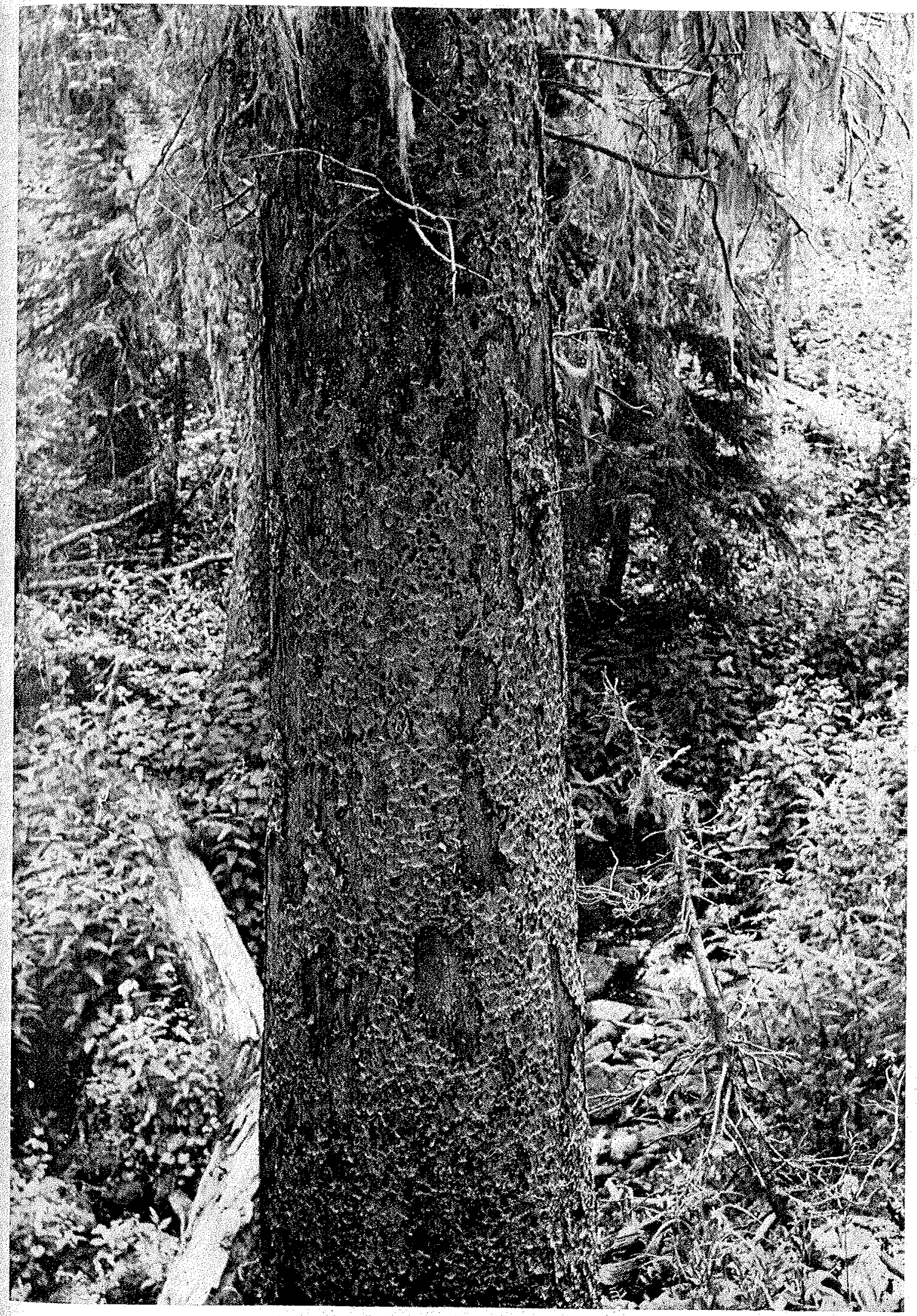

FIG. 2.-A beetle-infested spruce tree on which woodpeckers have fed intensively. 


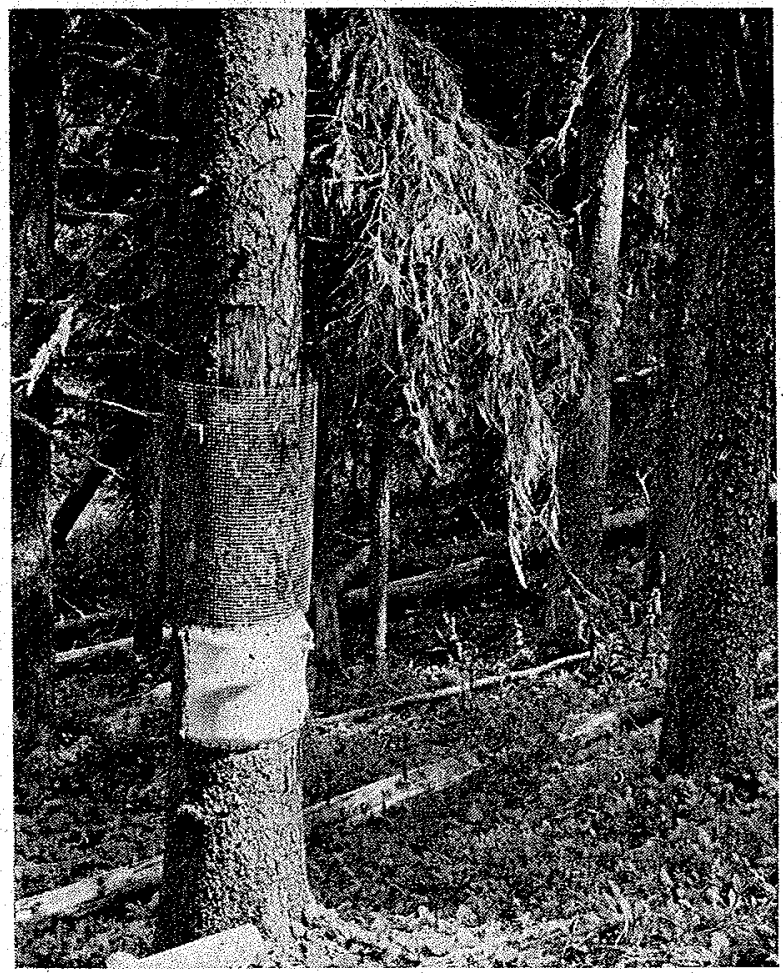

Frg. 3.-A spruce tree with wire cage in place to prevent woodpecker feeding. The white cloth exclosure was used to measure effects of other predators and of insect parasites.

can expect a higher percentage of mortality than that observed by Hutchison.

Yeager (1955) found that at a peak the number of woodpeckers was 9 per acre in a forest infested with Engelmann spruce beetles. It was not determined whether this was due to concentration or reproduction. The decline in numbers of woodpeckers after the peak and during the decrease in insect population might indicate that concentration was a major factor. Woodpeckers have been observed to concentrate in small epidemic spots of beetle infestation. The most recent of these was on the Rio Grande National Forest during 1956-57.

Collection of Data.-The effects of feeding by woodpeckers were studied on 225 spruce trees at 10 locations. Two-hundred and fifty trees (25 at each location) were selected in the fall of the year shortly after having been attacked by beetles. Twenty-five of the 250 were rejected after the attacks failed to develop. At the time of selection, hardware cloth ( $\frac{1}{2}$-inch mesh, $2 \frac{1}{2} \mathrm{ft}$. width) was placed around the trees, the lower edge 3 to 4 feet from the ground. These cages were designed to prevent woodpecker feeding in the bark area covered (fig. 3).

The cages were left on the trees through the winter and until the following August. By then most of the beetles had reached the adult stage. They were ready to emerge and enter the bases of trees for hibernation, and woodpeckers had about completed feeding on the insects in these trees. Consequently, a fairly accurate measurement of the effect of woodpecker feeding on beetle populations could be made.
The populations counted were the numbers of beetles in two samples from each tree, one from the area pro. tected by the cage and the second from the unprotected area directly above the cage. Each sample consisted of the beetles in and under two $6-\times 6$-inch squares of bark, one from the north and one from the south side of the tree. The samples were from the lower bole (between 4 and 7 feet from the ground), where large numbers of spruce beetle attacks are found (fig. 4).

The data in figure 4 were obtained by cutting 15 trees in one of the study areas and sampling at the heights indicated. The same type of distribution was found in studies in other areas in Colorado (Massey \& Wygant 1954, Nagel et al. 1957).

In addition to population counts, each tree was clas. sified by woodpecker work: Three broad classes were used, each based on percentage of tree bark area containing evidence of woodpecker activity between 4 feet and the uppermost woodpecker feeding.

Light-Very little disturbance of outer bark flakes, may have scattered small patches of wood showing, woodpecker work generally confined to scattered holes in the bark over an area of less than $25 \%$ of the total surface.

Moderate-A large portion of the outer bark flakes removed, always has small to large patches of wood showing, some part of surface area lacks evidence of any woodpecker activity. woodpecker work general over an area of up to $75 \%$ of the total surface.

Heavy-Practically all of the outer bark flakes removed, many large patches of wood showing, very little area withont evi. dence of woodpecker activity, woodpecker work general over more than $75 \%$ of the surface area.

Two intermediate classes were added to the classifica. tion, light to moderate and moderate to heavy. These special classes were used where one aspect of a tree showed one class and the opposite aspect showed an other. More complicated elassifications would be difficult to apply in the field. The three broad and two intermedi

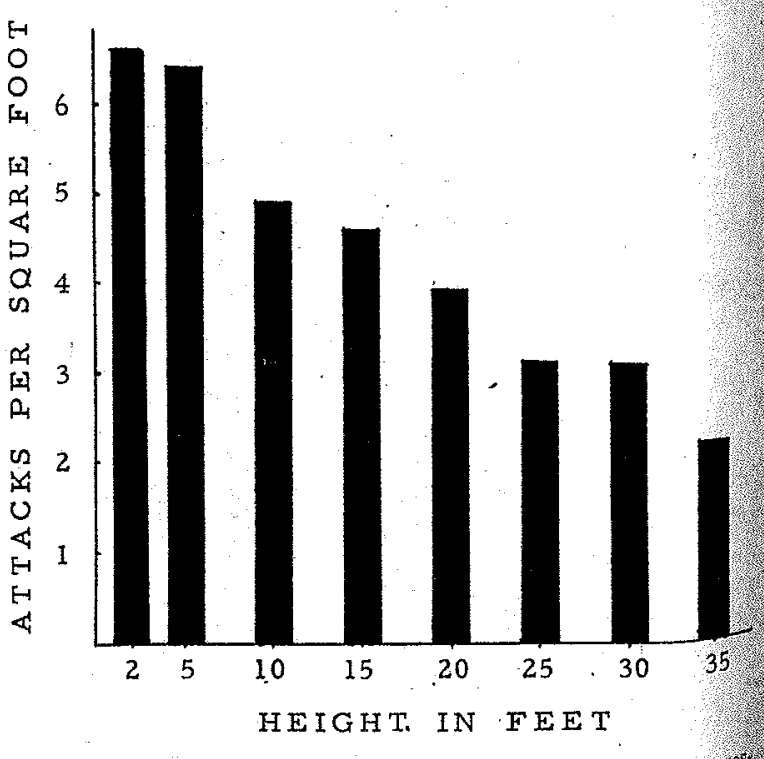

FIG. 4.-Density of Engelmann spruce beetle attacks at progret sive heights above ground on the boles of spruce trees, Colorads 1956. 
Table 1.-Average number of spruce beetles per one-half quare foot of bark, by woodpecker feeding class.

\begin{tabular}{|c|c|c|c|c|}
\hline \multirow{3}{*}{$\begin{array}{l}\text { Chass OF WOOD- } \\
\text { pECKER FEEDING }\end{array}$} & \multicolumn{4}{|c|}{$\begin{array}{c}\text { BeEtle SuRvival Per } \frac{1}{2} \text { SQ. FT. } \\
\text { OF BarK }\end{array}$} \\
\hline & \multicolumn{3}{|c|}{ Number of Trees } & \multirow{2}{*}{$\begin{array}{c}\text { Per Cen } \\
\text { Redue- } \\
\text { tion }\end{array}$} \\
\hline & Sampled & Caged & Uncaged & \\
\hline igh & 41 & $20 \pm 4$ & $11 \pm 3$ & 45 \\
\hline at to moderate & 24 & & & \\
\hline derate & 36 & $44 \pm 5$ & $16 \pm 4$ & 64 \\
\hline Moderate to heavy & 28 & & $8 \pm 2$ & 84 \\
\hline Heavy & 96 & $57 \pm 4$ & $1 \pm \frac{1}{2}$ & 98 \\
\hline
\end{tabular}

ate classes were not difficult to recognize after a little practice.

Trees are usually, attacked in late June and July. In a short time, woodpeckers commence feeding on the parent adults in the egg galleries. Thus, the tree will show evidence of feeding by the presence of individual holes in the bark at the ends of egg galleries. As winter progresses, the feeding becomes more general, and by spring most of the woodpecker work has been done. Some woodpecker feeding continues during the summer/but generally' not enough to change the classification from one category to another.

Anatysis. - The average numbers of beetles found in the various classifications are shown in table 1 . The beetle survival in caged areas was progressively greater from the light to the heavy woodpecker feeding class. This variable survival was due to the presence of trees containing broods of varying density within the stands. Logically, tor a tree to be heavily worked by woodpeckers, it must contain many beetles, thus lightly infested trees would be non-existent in the heavy woodpecker classification. In the light woodpecker classification, the proportion of lightly infested trees may be very large, resulting in lower average survivals in the caged areas. The $45 \%$ reduction in surviving beetles in trees lightly worked by woodpeckis might seem too large. However, on a lightly infested tree, light woodpecker work could result in a percentage eduction comparable to that caused by heavy woodjecker work on a heavily infested tree.

Table 1 expresses the averages found in the samples. The variability in the samples must also be expressed nore clearly than is shown by the standard errors. One rroblem that cannot be avoided stems from the variation a the population within the tree. The survival count in aged bark must be made a few feet from the count in aark not caged. Because of this and the population variafion, there are some samples containing more survivors in he uncaged than in the caged area. The survival was extremely variable in the moderate and light woodpecker dasses. In the heavy class practically all samples in the uneaged areas contained no survivors; thus, the variability in this class was very small. The range of observations in caged and uncaged bark areas are shown in table 2.

An analysis of the data showed a significant relationship between survival in uncaged areas of bark and two variables; (a) number of survivors in caged areas, and (b) the woodpecker classification together with number of survivors in caged areas. Other variables that showed no
Table 2.-Range of data in samples from caged and uncaged bark areas.

\begin{tabular}{|c|c|c|c|c|c|}
\hline \multirow[b]{3}{*}{$\begin{array}{l}\text { CtaAss of Wood- } \\
\text { PECKER FEedING }\end{array}$} & \multicolumn{3}{|c|}{ NuMBer of } & \multirow{2}{*}{\multicolumn{2}{|c|}{$\begin{array}{c}\text { MAXIMUM } \\
\text { SURVIVAI } \\
\text { BEETLES PER } \\
\frac{1}{2} \text { SQ. FT. }\end{array}$}} \\
\hline & \multirow[b]{2}{*}{$\begin{array}{l}\left(\frac{1}{2} \text { sq. ft. }\right) \\
\text { Samples }\end{array}$} & \multicolumn{2}{|c|}{$\begin{array}{c}\text { Samples } \\
\text { with Zero } \\
\text { Survival }\end{array}$} & & \\
\hline & & Caged & $\begin{array}{l}\text { Not } \\
\text { Caged }\end{array}$ & Caged & $\begin{array}{l}\text { Not } \\
\text { Caged }\end{array}$ \\
\hline Light & 41 & 9 & 14 . & 135 & 98 \\
\hline Light to moderate & 24 & 1 & 7 & 118 & 114 \\
\hline Moderate & 36 & 2 & 9 & 109 & 89 \\
\hline Moderate to heavy & 28 & 0 & 6 & 116 & 47 \\
\hline Heavy & 96 & 2 & 77 & 172 & 43 \\
\hline
\end{tabular}

significant relationship were the number of beetle entrance holes and the number of inches of egg gallery.

Although no relationship was shown between inches of egg gallery and survival in uncaged areas, there is a relationship between inches of egg gallery and survival in caged areas. This brings out the effect of over-population in beetles. When galleries become too numerous in the samples, the surviving population is reduced. This factor was not apparent in uncaged areas because of the large number of samples that contained no surviving brood. The effects of over-population in terms of surviving beetles and number of inches of egg gallery for the 225 trees sampled are shown in table 3 . The largest average survival was found in the samples containing between 41 and 50 inches of egg gallery per square foot. The number of entrance holes shows a similar but more variable relationship than inches of egg gallery.

Table 3.-Average survival of beetles compared to the amount of egg gallery present in the samples.

\begin{tabular}{|c|c|c|}
\hline $\begin{array}{c}\text { EgG Gallast } \\
\text { PER SQ. FT. }\end{array}$ & $\begin{array}{l}\text { SAMPLES } \\
\left(\frac{1}{2} \text { sq. ft.) }\right.\end{array}$ & $\begin{array}{c}\text { SuRvival of BeETLES } \\
\text { IN CAGET ARmas- } \\
\text { PER SQ. FT. }\end{array}$ \\
\hline (inches) & (number) & (number) \\
\hline $0-10$ & 8 & 4.0 \\
\hline $11-20$ & 25 & 18.5 \\
\hline $21-30$ & 39 & 36.9 \\
\hline $31-40$ & 45 & 49.4 \\
\hline $41-50$ & 36 & 61.3 \\
\hline $51-60$ & 30 & 57.8 \\
\hline $61-70$ & 14 & 50.1 \\
\hline $71+$ & 23 & 45.9 \\
\hline
\end{tabular}

\section{References Cited}

Hutchison, F. T. 1951. The effects of woodpeckers on the Engelmann spruce beetle, Dendroctonus engelmanni Hopk., Master Thesis, Colorado State University. 73 pp., illus.

Massey, C. L., and N. D. Wygant. 1954. Biology and control of the Engelmann spruce beetle in Colorado. U. S. Dept. Agri. Circ. 944.35 pp., illus.

Nagel, R. H., David McComb, and F. B. Knight. 1957. Trap tree method for controlling the Engelmann spruce beetle in Colorado. Jour. Forest. 55(12): 894-8.

Yeager, L. E. 1955. Two woodpecker populations in relation to environmental change. The Condor 57(3): 148-53.

U. S. Forest Service. 1955. Timber Resource Review, Ch. IV, $69 \mathrm{pp}$. 